Saudi Journal of Business and Management Studies Abbreviated Key Title: Saudi J Bus Manag Stud ISSN 2415-6663 (Print) |ISSN 2415-6671 (Online) Scholars Middle East Publishers, Dubai, United Arab Emirates Journal homepage: https://saudijournals.com/sjbms

Original Research Article

\title{
Theoretical and Sociological Aspects of Leisure Time
}

\author{
George F. Zarotis ${ }^{1 *}$, Walter Tokarski ${ }^{2}$ \\ ${ }^{1}$ Lecturer at the Faculty for Human Sciences, University of the Aegean, Faculty of Human Sciences, Rhodes, Greece \\ ${ }^{2}$ German Sport University, Am Sportpark Müngersdorf 6, 50933 Köln, Germany
}

DOI: $10.36348 /$ sjbms.2020.v05i07.002

| Received: 27.06.2020 | Accepted: 06.07.2020 | Published: 08.07.2020

*Corresponding author: George F. Zarotis

\section{Abstract}

Our society is undergoing a constant change that encompasses all areas of human life. The importance of work and free time, the two central areas of life, has undergone a major change. The reasons are obvious: work alienation, increasing prosperity and the change in traditional social values have given greater importance to leisure time [1]. But despite the multifaceted social and technical changes over time, people have not realized the character and properties of time. The ultimate goal of this research is the theoretical and sociological approach to leisure time. The method adopted for the study was a review of the relevant literature. In the light of the present study, it is found that problems usually arise rather from human attitude towards time than time itself. The concept of time is comprehensive and encompasses physical and biological as well as psychological and social processes, which overlap and influence each other. The perception of time is not the same but varies depending on the person or the situation. Time seems to have a different qualitative and changing meaning. So, as people and their world change, so does the way they perceive time and the measures they take to deal with it. The way someone interprets past events, or thinks about the present and the future differs to a great extent from person to person. Some people consider their present life as a result of their past attempts; others think less of the past and enjoy life in the present, while others believe in the permanent repetition of already known things. The use of time in the course of the day or the week was the subject of research. No doubt, the 24 hours of the day pass just as quickly whether you are old or young, a woman or a man. Time is a phenomenon that is difficult to comprehend and perceive. Time is not always the same time. But with a closer understanding of the prevailing time apprehension, time budget and time patterns we can identify specific attitude structures towards time. Finally, it becomes clear that today we cannot talk about either leisure time park or leisure time society, since time is to a great extent allocated between managing work, house chores and essential hygiene as well as sleep. Only a few have the power to change their own time pattern and develop new dynamics.

Keywords: Concept, Character \& Time Sense, Time Budgets, Time Structures and Time Templates.

Copyright @ 2020: This is an open-access article distributed under the terms of the Creative Commons Attribution license which permits unrestricted use, distribution, and reproduction in any medium for non-commercial use (NonCommercial, or CC-BY-NC) provided the original author and source are credited.

\section{INTRODUCTION}

Lack of time and unnecessary waste of time, the need for time and the excess of time coexist in society. Time is a precious commodity that has a different meaning for everyone. On the one hand employed people experience lack of time, while on the other the unemployed have sufficient time, a fact which may also cause them problems. This relationship has always existed though throughout history there were other forms of appearance that probably had affected different social groups compared to today. But despite the multifaceted social and technical changes in the course of time, people have not realized the character and properties of time.

The following is an overview of the human attitude towards time and an indicative examination of some of the key principles and implications of time, presenting a 'historical overview of the evolution of time' based on Hawking's [2] and Dux's [3] perception / approach. Depending on the theoretical approach the leisure time research provides different explanatory conclusions about the term leisure time. However, none of these theories alone offers a complete explanation of the concept. Due to the fact that leisure time is more or 
less considered interdependent with work, the sole description of the concept that can be agreed upon is offered by the term non-working [4].

Taking into account the shifting importance between work and leisure time and at the same time the increasing prosperity, the value of leisure time is increasingly appreciated. It has become an important factor in assessing quality of life [5, 6]. In view of current social developments, as well as in relation to the European market and the widespread changes in eastern and middle Europe as well as the expected developments in the field of leisure time, until now, the possibilities for predicting or estimating trends in the field of scientific Methodology have not been sufficiently developed. Due to the special nature of leisure time science as spectrum science or diachronic science, in the past a large number of methodical applications have been implemented, which have their origins in the fields of Pedagogy, Social Sciences, Social Psychology, Science of Culture, Media Science, Sports Science etc. At this point, time budget research is - especially internationally - a particularly important part of empirical leisure time research. Thus, in previous years it has been possible to gain basic knowledge about time expenditure (extent) and time consumption (use) in comparable industrial companies [7]. Time budget studies on the one hand have the advantage of providing a useful empirical basis in the field of leisure time, but at the same time they have a relatively multifaceted character. In view of this theoretical and methodical lack of classical time budget searches, in recent years a new theoretical proposal has emerged, which by constructing 'time templates' (i.e. the time combination and the individual evaluation of certain activities and successive activities) complements the objectively found ways of behaviour with a subjective and individual evaluation of these activities. Thus, as opposed to what was common so far, activities are not just registered for a certain period of time, but rather formative constructs are developed, which codetermine as ideal or real logical, cognitive representations, innate, time-socially acquired or motivated manifestations of the actions of people, organizations, and legal entities in all aspects of temporal structure [8].

\section{METHODOLOGY}

The present research is a bibliographic review study, presenting the critical points of the existing knowledge about the "THEORETICAL AND SOCIOLOGICAL ASPECTS OF LEISURE TIME". There is no specialized and comprehensive work on this subject in the international relevant literature. This work endeavors to cover this gap and will perhaps also be a useful aid for those who in the future will attempt similar efforts. The main aim of the bibliographic review is to frame the study within the "body" of the relevant literature. The review of the current study concerns clearly formulated questions and uses systematic and explicit criteria for critically analyzing a body of published papers by summarizing, sorting, grouping and comparing.

\section{Bibliographic Review Study The Concept and the Character of Time}

Usually the problems arise rather from human attitude towards time than time itself. The concept of time internationally cannot be confined to only one type of approach (e.g. physics approach), as was the case with Albert Einstein. The concept of time is comprehensive and encompasses physical and biological as well as psychological and social processes, which overlap and influence each other $[9,10]$. This multi-faceted approach points to the great complexity of the phenomenon of time, which is variously experienced in our daily lives. The perception of time is not the same but varies depending on the person or the situation. Therefore:

1. Time is not the same time. So, understanding what time is depends on the situation and changes in the course of life.

2. Time has a different meaning for younger people than for older ones and for unemployed people than employed ones.

3. Working time is different from leisure time, even in the case where people do the same thing in their leisure time as in their working time.

4. Time for family, time for love, time for celebration and mourning is completely different from shopping time, sleeping time, gardening time and time dedicated for oneself.

From the above it is evident that time has different qualitative and changing meaning. Thus, as people and their world change, so does the way they perceive time and the measures they take to deal with it. Also, in the various sciences, time was sometimes given greater and sometimes less attention. Depending on the level of knowledge and development, time went through various stages of presentation and theoretical elaboration on time models. The direction and continuity of time were the major research topics of ancient and medieval philosophers as well as metaphysicists. The relevance of time and its evolution as something absolute that always moves forward play essentially no role in science anymore, because they affect current everyday human performances as they did before. On the contrary, perceptions about relative time, perceptions about irreversibility and self-organization, evolution, time hierarchy, time rhythms, time sense, experience of time and time systems are now central topics of discussion in the scientific research about the phenomenon of time. Perceptions of the meaning of time as something relevant are mixed with ancient perceptions / approaches in the everyday world in a conflicting image of time, in an, according to the situation, overlapping blend of concrete and vague, realism and fantasy. Usually for the modern man there 
are many conceptions of time, many time rhythms and time systems at the same time. Time for the modern man has many faces and forms. We are aware of the fact that time goes by constantly every New Year's Eve, just as the new year begins. We experience the fact that time is irreversible - and therefore final - at every birthday, when we celebrate, namely we grow up. But the fact that time is at the same time reversible is shown by the repeated circles such as night and day, the seasons of the year, or even the pace of the weekday from the working day to the weekend, the course of life from training to work and retirement, from birth to death. From the point of view of psychology, every person experience time subjectively. Everyone knows from experience that good times are very short, while bad times are long. Many people claim that nowadays time passes faster than before. This is based on the speed of aging, knowledge and ability, but also on the increase in the amount of new stimuli, developments, products, etc $[9,10]$.

The individual time pattern of people is made up of a large number of elements that not everyone realizes. These elements can have a character that is specified by others (definitive), a character that obliges the individual (mandatory) or even a freely formed (reformative) character. Therefore, time is structured hierarchically. For example, former German Chancellor Kohl characterized Germany as a "leisure time collective park" [11]. By this he meant that the Germans had too much free time and in his opinion they should work more. In this way he expressed a certain kind of time hierarchy according to which work precedes leisure time, an approach which may not be accepted by all citizens.

People generally realize that they live in different time systems only when there are problems with time: for the normal working citizen after the time spent in work follows free time. But people who work at home, in the course of their daily lives, have a constant shift of roles from work to leisure. Within a family often there are conflicts between work hours, school hours and time for housework, as well as the free time of different family members, so often there is only little space for shared time: then time synchronization becomes difficult or is not achieved at all. The same applies to the synchronization of working hours in public institutions and working hours in businesses, as well as shift schedule and leisure time. It was only after the introduction of the morning programs on television a few years ago that those who worked in the afternoon and evening were able to watch television. With the introduction of the flexibility of working hours in certain industries and the introduction of the new store opening hours some time systems have been changed. It is expected that the problem of time synchronization will intensify in the future $[11,12]$. The situation is made more complicated by the fact that there are different time structures with different time routines.
Often every day of the week has a different time structure: Monday is considered a typical day for television and has a different character, another time structure than for example Thursday, which is considered a day, e.g., for the club. Friday and Saturday are considered less stressful, intense days, while Sunday has the characteristics of a rather slower life with rest, sleep, socializing, excursions, eating out, etc.

From a religious point of view there is a different perception of time since it is taught that men are small passing parts of eternity. According to church time does exist, but compared to eternity, the time we live in plays almost no role. So, our existence is a small piece of eternity, the window into time. Other times have respective windows in time. This way of approaching time as part of eternity has become less popular with the decline of religions in advanced industrial societies. What counts today is the moment $[11,12]$.

\section{The Sense of Time}

The way someone interprets past events, or thinks about the present and the future differs to a great extent from person to person. Some people consider their present life as a result of their past attempts; others think less of the past and enjoy life in the present, while others believe in the permanent repetition of already known things. These dispositions are characterized as time sense. The particular way in which individuals experience and evaluate events in the past, present and future determines how they feel and how they shape their lives. Therefore, it is about the subjective interpretation each person makes, e.g. in the form of hopes, fears or expectations - changes and events, as well as the person's actions in the past, present and future [13]. Time sense is the means of the individual to classify in time the changes he or she perceives consciously [14].

\section{There are four forms of time sense [15-16]:}

1. In people with the so-called circumstantial sense of time only the present plays a role in their lives, in terms of "here and now", that is, the action of the individual is presented as if this current minute were the focus. As the saying goes, "In what I do I'm little interested in what happened yesterday and in what will happen tomorrow". Changes are perceived as arbitrary; their appearance is evaluated as unexpected. Circumstantial sense of time - according to new research - is more common in somewhat older people, in people with lower level of educational attainment, and is generally more frequently observed in men than in women.

2. People with the so-called cyclical sense of time also place the present in the center of their lives, but this is interpreted as a continuous repetition of already experienced processes. As the saying in this case goes, "I basically expect nothing new in 
my life. In any case things happen that I cannot influence at all." These people consider that changes are predestined. The cyclical sense of time is found more than anywhere else in older people and in the lower classes. Women are much less represented than men and in this sense of time. Studies show that people with a cyclical sense of time put less effort on the areas of housing, companionship, leisure time, social security, the environment and children.

3. In the so-called linearly closed sense of time, the past is meant as a decisive magnitude for the present, and the present presents a special possibility for shaping the future. Here, a certain outcome of evolution is accepted, e.g. a career goal. As the saying goes: "In my development I am moving towards a goal, the achievement of which I can influence with my actions." The linearly closed sense of time is more common in younger people, people with a high level of education and those in the upper classes. People with a linearly closed sense of time are more likely to have responsible jobs and decision-making powers than others.

4. In the so-called linearly open sense of time past, present and future are seen as a continuum: the present is perceived as a result of the past and the future is shaped by the present. People with a linearly open sense of time, however, lack a certain purpose in their lives, so shaping the present is central to this type as well. As the saying goes in this case, "What the future holds for me depends on what I'm doing today. But I don't know exactly what the future will be like." The linearly open sense of time is more common in younger and more educated individuals.

Despite the socio-demographic and local differences in Germany as a whole, the latter two forms of linear sense of time prevail and can thus be considered as characteristic of modern societies. The analysis so far has made it clear that the way people interpret past events, reflect on the present, and think about the future is extremely different for everyone. Some people consider their present life as a result of their past attempts; others think less of the past and enjoy life in the present, while others believe in the permanent repetition of already known things.

According to Haeder [15], these dispositions are characterized as time sense. The particular way in which individuals experience and evaluate events in the past, present and future determines how they feel and how they try to shape their lives. Therefore, it is about the subjective interpretation each person makes, e.g. in the form of hopes, fears or expectations - changes and events, as well as the person's actions in the past, present and future [13]. Time sense is the means of the individual to classify in time the changes he or she perceives consciously $[14,17]$.
Haeder [15] distinguishes four forms of time sense:

1. The circumstantial sense of time. In the case of people with the so-called circumstantial sense of time only the present plays a role in their lives. The "here and now" view dominates, that is, the individual's energy is focused on the present moment. This view is supported by the following position of this group of people: "In what I do I'm little interested in what happened yesterday and in what will happen tomorrow" [15]. The observed changes are perceived as arbitrary and their appearance is evaluated as unexpected. As new research shows, the circumstantial sense of time does not play a significant role. It is more common in somewhat older people, in people with lower level of educational attainment, and is generally more frequently observed in men than in women. Moreover, it is observed that people who perform frequently monotonous and physically heavy work have such a time sense.

2. The cyclical sense of time. People that have a cyclical sense of time also place the present in the center of their lives, whereas this is interpreted as a continuous repetition of already experienced processes. Usually these people have the following saying: "I simply expect nothing new in my life. In any case things happen that I cannot influence at all." These people consider that changes are predestined. According to studies, the cyclical sense of time is common in older people, over 60 , in people with lower levels of education, and in individuals that perform monotonous and physically heavy work. Women are also significantly less represented in this form of time compared to men. Studies show that people with a cyclical sense of time put less effort on the areas of housing, companionship, leisure time, social security, the environment and children.

3. The linearly open sense of time. According to this form of time, past, present and future are seen as a continuum: the present is perceived as a result of the past and the future is shaped in relation to the present. People with a linearly open sense of time lack a certain purpose in their lives. Thus, shaping the present is the center and the basis for tomorrow. This view is better understood by the following position of some people: "What the future holds for me depends on what I'm doing today. But I don't know exactly what the future will be like." Research has shown that the linearly open sense of time is more common in younger and more educated individuals.

4. The linearly closed sense of time. As was the case in the linearly open sense of time, also in the linearly closed sense of time the past is the criterion for defining the present, and the present gives the special possibility for shaping the future, e.g. a career goal. In this case, the following position applies to some people: "In my evolution I am moving towards a goal, the achievement of 
which I can influence with my actions." Haeder [15] supports that the linearly closed sense of time is more common in younger people and people of the upper classes. People with a linearly closed sense of time are more likely to have responsible jobs and decision-making powers in comparison to others. They also make significantly greater efforts in the areas of home, companionship, leisure time, work, social security, the environment, children and education.

The results of German scientific research have shown that the model of the linearly open sense of time is the most widespread in Germany as a whole, but the cyclical sense of time has also become more important a few years now. A linearly open sense of time involves a strong orientation to the present as an element of shaping the future. However, these people view the future ultimately without having a personal purpose. On the contrary, according to the cyclical sense of time, everything is presumed to be predetermined and cannot be influenced. Taking into account the two conclusions of the study, it appears that time sense takes on the character of the barometer of population's disposition, where it signals: the present is at the center of life. However, there is often no goal orientation, and resignation from the future is increasing $[15,16]$.

\section{Time Budgets}

The use of time during the day or week has been the subject of research. Undoubtedly, the 24 hours of the day are spent just as fast regardless of whether someone is old or young, a woman or a man. With respect to the question of how people's time budgets are in modern society, official statistics provide the following conclusions about how Germans use their time $[18,19]$. According to the results, people with an average age of over 12 years devote throughout a whole week just four hours daily for schooling, education and occupational activities. They spend a little more time doing chores for home and family. Man sleeps one third of the time and needs more than two hours for personal things like hygiene, clothing and food. Around $20 \%$ of the day, that is, about five hours, is spent for the media, conversations, sports and culture. These general data give a first glance at how the Germans spend their time, but average values in some cases say very little. One has to look at the issue more closely to find that the use of time is very different in individual groups of the population: For example, workers, who make up a large group of the population, work from Monday to Saturday for six hours a day, plus an average of 30 minutes of driving. House chores take about 2 hours and 45 minutes for working people, while free time occupies 3 hours a day. Phone calls, conversations, and meeting with friends take about 1 hour and 30 minutes a day, with more than 10 hours remaining for sleep, bodily care, and food. These average values can vary greatly in individual cases, such as parents raising children alone, large families, freelancers, etc. As regards the pensioners' time budget, their day is not just leisure time. Many things in old age take a little longer. So, the time for house chores, which is 2 hours and 45 minutes for working people, is in fact twice as much for them. Also, they need more time for sleep, bodily care and eating by about 2 hours and 30 minutes. So, the leisure time of this group of people is apparently more than that of the working people, but not so much, that one can conclude that pensioners have unlimited leisure time. And in this social group, times can vary in individual cases, such as health status, income, home situation, existing assistance, etc. Young people are busy with school, homework or vocational training, daily, on average 4 hours and 30 minutes, seven days a week. They spend an additional 1 hour and 30 minutes to help with house chores. They spend 6 hours and 30 minutes for leisure time, while 11 hours and 30 minutes for sleep, bodily care and food. From the above figures of the time budget of different groups of the population it is found that leisure time is not enough. If sleep, bodily hygiene and eating time are deducted, then working people use twice as much time for their work and house chores than for leisure time, which is 2: 1 rather than 3: 1. In addition, if one also takes into account the overtime concealed working hours which in some cases accounted for $41 \%$ of the total working time and more, then it becomes clear that the "leisure time collective park" mentioned by Kohl, the former chancellor of Germany, is a myth. So, we can't be talking about leisure time park and leisure time society $[20,7]$. The leisure time budget consists of two components: the financial budget and the time budget for leisure time. The financial budget represents citizens' expenditure for leisure time and is calculated annually by the Federal Statistical Office in the context of statistics on the allocation of family budget money. According to it, in 1996, the percentage of leisure time expenses in the family spending money budget, in households of all kinds, amounted to about $15 \%$, and this percentage remained constant throughout the year - even in times of financial crisis. Most of the leisure time budget is spent on vacations, transportation fares in leisure time and radio - video, up to a total of $60 \%$ [21]. The time budget of the population is similarly calculated by the Federal Statistical Office, most recently in 1992 [18, 19]. The time budget is the $\log$ of the succession and duration of activities performed by a person during an earlier time period. The calculation is usually done through calendars and questionnaires. In total, Germans from the age of 12 spend an average of almost four hours daily for schooling, education and / or livelihood activities throughout the week. They spend a little more time on house chores and on the family. Humans sleep the one third of their time and need more than two hours for personal things like hygiene, clothing and food. The rest - that is $20 \%$ or about five hours - is claimed by the media, discussions, sports and culture - hence leisure time. In individual population groups - e.g. working people, retirees, men and women, as well as adolescents, time allocation varies considerably from 
person to person. Time budget calculation data show that leisure time is not as much as we often think: If sleep, physical hygiene and eating time are eliminated, working people normally spend more than double time for their profession and house chores in comparison to their free time. In other social groups the proportion is more favorable.

\section{Time structures and time templates}

A time template is a pattern of activities, events, or experiences that can be traced back to a certain time period (e.g. day, week, month, year) and not only as real, but also as ideal, i.e., hypothetical or desired templates. Thus, the lecture schedule in a students' weekly curriculum along with their free hours form a real time template of a semester week. The entry of leave days into an annual plan along with working days forms a real time template of a working year. The desired course of activities during a two-week holiday is an ideal holiday template [22]. The application of time templates is based on the recognition that in modern societies the synthesis of time templates for specific purposes (work, leisure time, family, etc.) results in an activities structure model of a society or a social class, its potential change, and its quality of life. In this application, time is examined not only at real but also at ideal angles, that is, in addition to the person's real time templates, there are also examined the subjective desired templates or the templates that exist as guiding ideas and time rhythms, including their causes as well as the history of their creation. Then the "successfully accomplished", that is, subjectively satisfactory time templates, are the results of balancing external (time frames for work organization, household structures, travel plans, physiological arrangements, etc.) and internal (individual needs and preferences, internal obligations, habits, etc.) time data. Studies show that some activity time sequences can be evaluated more positively than others. In this way, some students of different disciplines find the time templates organized in the morning as a school to be ideal for their studies, for many people the time succession visiting the swimming pool - visiting the cafeteria shopping is a combination of less stress than for others, older people spend their mornings as working days, mainly in the light of work-related or similar to workrelated activities, while afternoons are devoted to leisure time activities. The reference of the application of these research results is evident: public bodies (e.g. Higher Education Colleges, Universities, Town Halls, Counseling Centers etc.) as well as private service providers (e.g. sports centers, clubs, outpatient clinics of health care institutions, etc.), since they can more precisely determine their opening hours, measures and offers, and furthermore according to specific target groups. The schedules offered can be better tailored with regard to their time succession (e.g. holiday programs, educational programs, and training programs). Time coordination problems (e.g. between family members, employers and employees, citizens and municipal administration) can be identified and minimized.

Time templates are patterns of activities, events, or experiences that can be set over a given period of time, and not only as actually existing (real), but also as desirable (ideal) models. According to time templates, days, weeks, months, and years are characterized by certain content such as work, leisure time, sleep, food, conversations, etc. However, it is not always known according to which templates this content is classified or what template people want. Regarding fixed-time work, it is relatively simple and understandable for most people: Working time is most often specified, e.g. work from 6 am until 3 pm or from 8 am to $5 \mathrm{pm}$. However, with the flexibility of working hours, the first conflicts began and the following questions arose: Which working time model is more preferred? When and for how long does one want a break? Is it preferable to work more for four days and go home early on Thursday? Or would it perhaps be better to allocate the 38.5-hour work week to five or six days of work only in the morning or only in the afternoon?

The schedule of lectures and seminars on a weekday or in the course of a week along with the free hours form the real time template of a student. The entry of leave days into an annual program is the employee's work and vacation time template. The desired time termination of some leisure activities and other activities forms the vacation time template. These examples show that knowledge of these time templates is of the utmost importance. For example, those who offer sports activities such as tennis courts, swimming pools, sports and leisure studios or even owners of cinemas, elementary schools, concert organizers, they could make more accurate and better customer-oriented offers if they knew more and realized what time templates are. Optimal adjustment of the operation hours of a leisure bath to the time template of specific social groups could be made more accurately. In addition, employers could have more satisfied employees, due to a work-time offer that would cover well their personal desires, would result in better utilization of time by the employees and thus could reduce absences [8].

Surveys about students in various Higher Education Institutions in Germany have shown that there are time classification templates of lectures and seminars that are perceived by students as personally desirable or personally undesirable. An important element for the evaluation was the alternation of study hours during the week with the respondents' free time, and the existence or absence of stress. The curricula that received positive evaluation were distributed in the morning as at school. On the contrary, bad reviews were received by centralized programs, e.g. if the courses were concentrated in just two days of the week. Also, 
the courses that started late in the day (afternoon classes) and the time partitioned programs were less accepted. However, there were slight differences with regard to leisure time and stress: Centralized programs, that is, the concentration of courses in two days, were considered favourable for leisure time, but in terms of stress they were poorly scored. Various social groups rated poorly the curricula that started late in the day, while on the other hand, they considered favourably the ones that included a lunch break. Students, who do not want to study at a fast pace, evaluated more favourably than others curricula that included lunch breaks and split / extended study programs. In particular, the students interviewed would be extremely willing to accept a more extensive curriculum if it were personally tailored to them [22]. Time is characterized as the core of the lifestyle, that is, the location of time for certain activities and actions, as well as dealing with it, is an important measure of determining a person's lifestyle. So, the lifestyle of unemployed people is changing not only because now they have lower income, but also because since they do not spend time on occupation, as they used to, they have more free time. A similar mechanism appears to retirees. Changing to a new work position with a different schedule, moving, reducing work to part-time, etc., also have such an effect. Research shows that most people to whom this had happened divide the time they gain simply by spending it on the rest of their activities, namely, on activities they would do anyway; it just takes them longer now. We call this fact conventional, and the aforementioned people 'conventional in relation to time'. Only a few people change their time structure to rearrange their time template, that is, to abolish old templates and create new ones. These people are called time pioneers and they organize their time more than others, they strive to earn time and can wait longer, they meet time spikes because they do not behave cyclically, set more time for themselves, create time balances and take care in order to have a slower pace in their lives. As mentioned above, only a few people change their lives with respect to time, when such an opportunity occurs, and try to gain some dominance over time. If we take into consideration the fact that every person in our society undergoes necessary professional, family and personal changes during his or her lifetime, we can conclude that seldom people deal with these changes in the perspective of time and thus the chances of change are eliminated [23].

Time is a phenomenon that is difficult to understand and conceive. Time is perceived differently in different life situations; it has many faces and many forms of appearance. Time is not always the same time. But with a closer understanding of the prevailing time sense, time budget and time templates we can identify specific attitude structures towards time. It is characteristic that most people in our society today are oriented to the present. Furthermore, resignation tendencies increase, according to the popular perception
/ position: "Anyway, I have no influence whatsoever over anything".

Finally, it becomes clear that today we cannot talk about either leisure time park or leisure time society, since time is to a great extent allocated between managing work, house chores and essential hygiene as well as sleep. Only a few have the power to change their own time pattern and develop new dynamics [24].

\section{CONCLUSION}

During the last three decades there has been a profound social change. Political, environmental and economic factors have had a growing impact on the professional, personal and leisure time sectors. Historically, leisure time in its present form is a social phenomenon that was shaped only by industrialization. While in earlier times, work was a means for the development of the individuals and helped them find meaning in their lives, this phenomenon shifted to the field of leisure time.

Reduced and more flexible weekly working hours made it possible to engage in leisure activities even on working days, mornings and evenings, and Saturdays. Shorter working period in a person's life, for example through early retirement, resulted in an increase of leisure time even at older ages [1].

It is common knowledge that today we are living in an age of more leisure time and we have multifaceted possibilities to take advantage of our free time. These opportunities are welcomed, and not only by the younger generations. All the studies about how leisure time is spent show that there are virtually countless possibilities in order to make good use of our free time. Statistics, for many years, have been showing more or less stable images.

However, it is questionable whether we already live in a leisure time society, as we sometimes claim. In any case, we live in a leisure time-oriented society, i.e. leisure time has not replaced work with its social significance, as the futurists of the fifties and sixties said - but also some of the current futurists - but subjective assessments of leisure time as well as citizens investment on leisure time have increased significantly.

\section{REFERENCES}

1. Zarotis, G., Tokarski, W., Kontakos, A., \& Katsagolis, A. (2011). Free time. Physical activity, Health and Quality of Life. Athen/Zefyri: Diadrasi.

2. Hawking, S. W. (1988). Eine kurze Geschichte der Zeit. Die Suche nach der Urkraft des Universums. Reinbek: Rowohlt.

3. Dux, G. (2017). Die Zeit in der Geschichte: Ihre Entwicklungslogik vom Mythos zur Weltzeit. Wiesbaden: Springer-Verlag.

4. Tokarski, W., \& Schmitz-Scherzer, R. (1985). 
Freizeit heute. In Freizeit (pp. 57-196). Vieweg+ Teubner Verlag.

5. Agricola, S. (1990). Zeitsouveraenitaet, Illusion oder Moeglichkeit. Erkrath: Deutsche Gesellschaft fuer Freizeit.

6. Rinderspacher, J. P. (2009). Zeitwohlstand und Zeitsouveraenitaet - gegensaetzliche Konzepte oder zwei Seiten derselben Medaille? In: Heitkoetter, M., Jurczyk, K., Lange, A., MeierGraewe, U. (Hrsg.): Zeit für Beziehungen? Zeit und Zeitpolitik für Familien, Opladen, 373-400.

7. Opaschowski, H. W. (2008). Einfuehrung in die Freizeitwissenschaft (5. Aufl.). Wiesbaden: VS Verlag für Sozialwissenschaften.

8. Dollase, R. (1995). Temporale Muster in der Freizeitforschung. Eine neue methodische Perspektive fuer empirische Untersuchungen. Spektrum Freizeit. 17(2-3), 107-111.

9. Mainzer, K. (2005). Zeit. Von der Uhrzeit zur Computerzeit. Muenchen: C. H. Beck.

10. Mueckenberger, U. (2011). Time Abstraction, Temporal Policy and the Right to One's Own Time. In: KronoScope, 1/2, 66-97.

11. Tokarski, W. (1994). Sport als Prophylaxe jugendlicher Gewalt? In: Das Rathaus. Zeitschrift fuer Kommunalpolitik 47, 10.

12. Deutsche Gesellschaft für Zeitpolitik (DGfZP). (2005). Zeit ist Leben. Manifest der Deutschen Gesellschaft für Zeitpolitik. Berlin.

13. Tokarski, J. S., \& Hopfinger, A. J. (1997). Constructing protein models for ligand- receptor binding thermodynamic simulations: an application to a set of peptidometic renin inhibitors. Journal of chemical information and computer sciences, 37(4), 779-791.

14. Rammstedt, O. (1975). Alltagsbewusstsein von
Zeit. In: Koelner Zeitschrift fuer Soziologie und Sozialpsychologie, 27(1), 47-63.

15. Haeder, M. (1996). Linear, zyklisch oder okkasional? Ein Indikator zur Ermittlung der individuell praeferierten Form des Zeitbewusstseins. ZUMA Nachrichten, 20:18-28.

16. Ebert, B. (2003). Diagnostik und Foerderung des Zeitbewusstseins bei Schluern der Primarstufe. In: Ricken, G./Fritz, A./Hofmann, C. (Hrsg.): Diagnose: Sonderpaedagogischer Foerderbedarf. Lengerich, 440-458.

17. Freericks, R., \& Brinkmann, D. (Hrsg.). (2015). Handbuch Freizeitsoziologie. Wiesbaden: VS Verlag für Sozialwissenschaften.

18. Statistisches Bundesamt. (1994). Wo bleibt die Zeit? Die Zeitverwendung der Bevoelkerung in Deutschland. Wiesbaden: Selbstverlag.

19. Statistisches Bundesamt. (2003). Zeitbudgetstudie Deutschland: Wo bleibt die Zeit? Die Zeitverwendung der Bevoelkerung in Deutschland 2001/02. Wiesbaden: Selbstverlag.

20. Garhammer, M. (1996). Desiderata der Freizeitforschung. Spektrum Freizeit, 18, 2-3.

21. Deutsche Gesellschaft für Umwelterziehung. (1998). Nachhaltigkeit und Umweltbildung. Krämer.

22. Dollase, R., Hammerich, K., \& Tokarski, W. (Hrsg.) (2013). Temporale Muster: Die ideale Reihenfolge der Tätigkeiten. Wiesbaden: SpringerVerlag.

23. Hoerning, K. H., Ahrens, D., \& Gerhard, A. (1997). Zeit-Praktiken. Experimentierfelder der Spaetmoderne. Frankfurt/Main: Suhrkamp.

24. Keupp, H. (1996). Produktive Lebensbewaeltigung in den Zeiten der allgemeinen Verunsicherung. SOS Dialog. 3:7. 